\title{
The approach to frostbite in Turkey: A retrospective study
}

\author{
Ilteris Murat Emsen MD
}

IM Emsen. The approach to frostbite in Turkey: A retrospective study. Can J Plast Surg 2006;14(1):21-23.

Increased participation in outdoor activities and an epidemic of homelessness have caused the incidence of cold injuries in the civilian population of Turkey to rise dramatically during the past 20 years. Knowledge of treatment is crucial for emergency physicians in rural and urban areas. Recent developments have significantly advanced the understanding of the pathophysiology of hypothermic and frostbite injuries. The authors undertook a retrospective review of frostbite cases in the East Anatolia region of Turkey. The mean altitude of East Anatolia is $1600 \mathrm{~m}$, and temperatures may be $-35^{\circ} \mathrm{C}$ at night and $-18^{\circ} \mathrm{C}$ in the morning in the cities and surrounding villages. Winter is prolonged and harsh, and freezing is a normal condition in this region. The socioeconomic level in this region is lower than other regions of Turkey. During the winter, roads may be closed for as long as five months, and most villages in East Anatolia have no medical units. Erzurum, one of the coldest cities in East Anatolia, is the only city with advanced medical hospitals in this region. Three hospitals in Erzurum were included in the present study: Ataturk University Medical Faculty, Erzurum Numune Hospital and Erzurum SSK Hospital. Frostbite case records and their properties are presented.

\section{Le traitement des engelures en Turquie : Une étude rétrospective}

La participation accrue à des activités extérieures et une épidémie de sansabris a provoqué une hausse marquée de l'incidence de lésions causées par le froid au sein de la population civile de Turquie depuis vingt ans. Il est essentiel que les médecins d'urgence des régions rurales et urbaines en connaissent le traitement. Des avancées récentes ont fait considérablement progresser la compréhension de la physiopathologie des lésions causées par l'hypothermie et les engelures. Les auteurs ont entrepris une étude rétrospective des cas d'engelures dans la région de l'Anatolie de l'Est, en Turquie. L'altitude moyenne de l'Anatolie de l'Est est de $1600 \mathrm{~m}$, et la température peut être de $-35^{\circ} \mathrm{C}$ la nuit et de $-18{ }^{\circ} \mathrm{C}$ le matin dans les villes et les villages avoisinants. L'hiver y est long et cru, et le gel, normal. Le niveau socioéconomique y est plus bas que dans les autres régions de la Turquie. Pendant l'hiver, les chemins peuvent être fermés jusqu'à cinq mois, et la plupart des villages de l'Anatolie de l'Est ne possèdent pas d'unité médicale. Erzurum, l'une des villes les plus froides de l'Anatolie de l'Est, est la seule ville de la région à être doté d'hôpitaux de soins avancés. Trois hôpitaux d'Erzurum ont participé à la présente étude : la faculté de médecine de l'université Ataturk, l'hôpital Numune d'Erzurum et l'hôpital SSK d'Erzurum. Les dossiers d'engelures et leurs propriétés sont présentés.

\section{Key Words: Cold injury; Frostbite; Hypothermia}

Cold injury is a danger in mountain climbing and other outdoor and recreational sports such as skiing and fishing. The symptoms are easily recognizable by experienced personnel, and prevention is mostly possible. Cold injury should be divided by pathological means into general hypothermia and local frostbite injuries. Recent developments have significantly advanced the understanding of the pathophysiology of hypothermic and frostbite injuries (1).

Life-threatening deep hypothermia with coma and insufficient circulation or cardiac arrest is often reversible with sufficient core rewarming. This is because of the high tolerance of hypothermic patients to hypoxia; clinical death is not like biological death (2). Diagnosing hypothermia requires a high index of suspicion. Restoring lost heat with careful attention to hemodynamics usually results in complete recovery (3). The change in core temperature that occurs as a result of exposure to cold air or water affects all body systems. A decrease in core temperature induces shivering, then muscle stiffness; depresses the central nervous and respiratory systems; triggers cardiac arrhythmias and vasoconstriction; and affects body fluid balance. Cold water immersion presents additional considerations, including the general shock effect on the cardiac and respiratory systems, and the triggering of the diving reflex when the entire body is immersed (4).
Predisposing factors may increase heat loss, decrease heat production, decrease the insulation of the clothing, make people especially susceptible to cold or make them behave carelessly. For example, marked increase in convective or conductive heat loss is often the immediate reason for frostbite. Wind (as described by the wind chill index) increases convective heat loss, and touching of metal objects increases conductive cooling. Poorly insulated clothing is also a common cause of frostbite. The insulating properties may be insufficient when clothing is wet, tight, permeable to wind or does not cover the cold-sensitive body parts. Individual factors predisposing to frostbite are careless behaviour, poor physical fitness, fatigue, dehydration, previous cold-related injuries, sickness or poor circulation in peripheral parts of the body. In cold weather, it is inadvisable to become fatigued to exhaustion, sweat excessively, wear tight and/or wet clothing, drink alcohol, smoke, or expose oneself unnecessarily to wind, metals or fluids (5). Frostbite has a spectrum of injury ranging from irreversible cellular destruction to reversible changes seen after rewarming. These changes include increases in tissue edema, circulatory stasis and progressive thrombosis leading to further tissue necrosis. For these reasons, it is often difficult at the time of surgical debridement to determine the extent of frostbite injury. This delayed tissue injury is similar to that seen in muscle during ischemia or reperfusion injury (6). 
TABLE 1

Results

\begin{tabular}{|c|c|c|c|c|c|c|}
\hline$\overline{\text { Case }}$ & Age & Sex & Cofactors & Involved organ & Frostbite degree & Result \\
\hline 1 & 67 & M & Chronic smoking & Bilateral feet, toes & Stage IV & Toe amputations \\
\hline 2 & 71 & M & Diabetes mellitus & Bilateral ankles & Stage IV & Amputation from bilateral $1 / 3$ distal tibia \\
\hline 3 & 12 & $\mathrm{~F}$ & No & Nose & Stage II & No complications \\
\hline 4 & 11 & M & No & Ear & Stage II & No complications \\
\hline 5 & 54 & M & Chronic obstructive lung disease & Bilateral legs & Stage IV & Amputation from $1 / 3$ middle tibia \\
\hline 6 & 82 & $\mathrm{~F}$ & Mental retardation & Bilateral hands, feet, fingers & Stage IV & Amputation of involved fingers \\
\hline 7 & 23 & $\mathrm{~F}$ & Schizophrenia & Bilateral feet, toes & Stage IV & Toe amputations \\
\hline 8 & 35 & M & Alcoholic & Bilateral hands, fingers & Stage III & Epigastric flap for reconstruction of finger defects \\
\hline 9 & 51 & $\mathrm{~F}$ & Diabetes mellitus & Calcaneal area & Stage III & Reconstruction with medial calcaneal flap \\
\hline 10 & 38 & M & Mental retardation & Bilateral plantar area & Stage III & Reconstruction with full-thickness skin graft \\
\hline 11 & 69 & $\mathrm{~F}$ & Angina pectoris & Pulps of $2,3,4$ fingers & Stage II & Secondary healing \\
\hline 12 & 53 & M & Alcoholism, chronic smoking & Foot, toes & Stage IV & Amputations of involved toes \\
\hline 13 & 18 & M & No & Pulps of fingers & Stage I & No complications \\
\hline 14 & 62 & $\mathrm{~F}$ & Asthma & Left thumb pulp & Stage II & Secondary healing \\
\hline 15 & 73 & M & Chronic smoking, Buerger disease & Bilateral $1 / 3$ distal tibia & Stage III & Bilateral amputation from $1 / 2$ distal tibia \\
\hline 16 & 46 & $\mathrm{~F}$ & No & Bilateral toes & Stage II & No complication \\
\hline
\end{tabular}

*In years. F Female; M Male

TABLE 2

Classification of frostbite

\begin{tabular}{|c|c|c|}
\hline Degree of injury & Clinical features & Outcome \\
\hline Stage I & White-yellow plaque, hyperemia, edema, causalgia and pain may indicate nerve damage & Tissue loss and necrosis are rare \\
\hline Stage II & Blisters containing clear or milky fluid; erythema and edema are common & Characteristic recovery without tissue loss \\
\hline Stage III & Deep, full-thickness skin necrosis & Tissue loss is common \\
\hline Stage IV & Cyanosis, gangrene and necrosis & Underlying muscles and bone are affected \\
\hline
\end{tabular}

Frostbite is best treated by physicians who are cognizant of the pathophysiology of cold injury. Although alternative methods of intervention are being tested, rapid rewarming and antiinflammatory agents are integral to treatment protocols $(2,4)$.

\section{PATIENTS AND METHODS}

The authors retrospectively reviewed patient records spanning from 1999 to 2004 from three hospitals in Erzurum, Turkey (Ataturk University Medical Faculty, Erzurum Numune Hospital and Erzurum SSK Hospital). Sixteen cases of frostbite were identified, and the records were collected for further review. All patients had been transferred to any one of these three hospitals from peripheral cities or villages after being treated in their local clinics. Age, sex, associated diseases, involved organ, frostbite degree and outcomes for these 16 patients were investigated. The results of the investigation are presented in Table 1.

\section{DISCUSSION}

There are three types of cold injury: tissue-freezing injury (frostbite), nontissue-freezing injury (trenchfoot, chillblain) and hypothermia. Frostbite occurs when temperature falls to $-20^{\circ} \mathrm{C}\left(28^{\circ} \mathrm{F}\right)$ and tissue freezes, resulting in the formation of intracellular ice crystals and microvascular occlusion.

\section{Pathophysiology of frostbite}

Tissue damage may result from direct cellular damage or the secondary effects of microvascular thrombosis and subsequent ischemia. The recognized changes during freezing are extracellular ice formation; intracellular ice formation; cell dehydration and crenation; abnormal electrolyte concentrations due to the above; and perturbations in lipid-protein complexes. With rewarming, the ice crystals melt and the injured endothelium promotes edema. Epidermal blisters form, and free radical formation continues the insult. Elaboration of inflammatory mediators, prostaglandins and thromboxanes induces vasoconstriction and platelet aggregation, which worsen ischemia.

\section{Vascular changes in frostbite}

The vascular endothelium is particularly susceptible. Seventytwo hours after freezing and thawing, the endothelium may be completely obliterated and replaced by fibrin deposition. Investigators also have observed electron microscopic evidence of perivascular fluid extravasation and endothelial swelling and lysis $(6,7)$. Predisposing risk factors contributing to frostbite:

- Substance abuse, especially alcohol;

- Psychiatric illness;

- Environmental factors (lack of appropriate clothing and weather conditions);

- Peripheral vascular disease (decreased blood flow);

- Age (elderly and very young); and

- Medications (eg, aminophylline, caffeine, Fiorinal [Novartis Pharmaceuticals Canada Inc] and ergot alkaloids).

Classification of frostbite

The classification of frostbite is presented in Table 2 . 


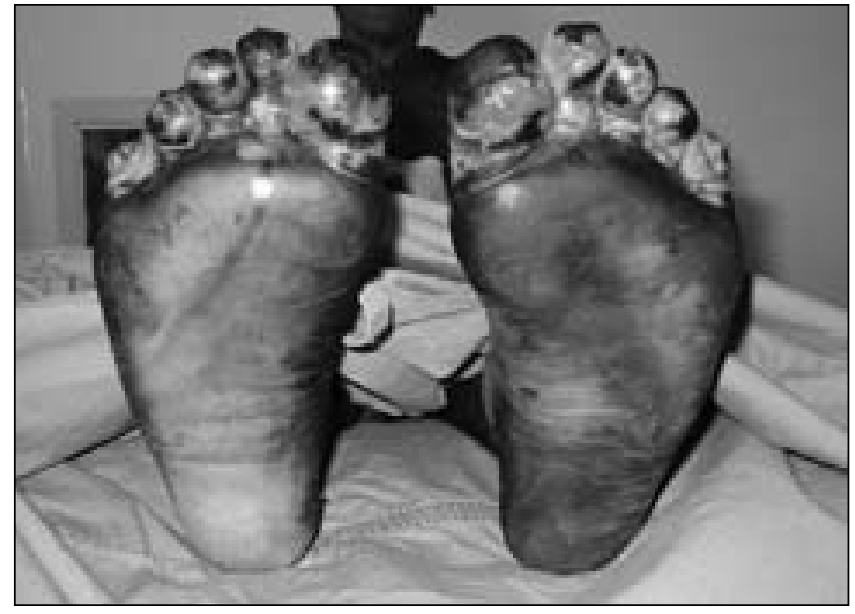

Figure 1) Frostbite is seen on bilateral plantar surfaces and toes of the feet

\section{Treatment of frostbite}

Rapid rewarming is the cornerstone in the acute management of frostbite. Immersion in water heated to $40^{\circ} \mathrm{C}$ to $42^{\circ} \mathrm{C}$ $\left(104^{\circ} \mathrm{F}\right.$ to $\left.108^{\circ} \mathrm{F}\right)$ is the standard of care for all degrees of frostbite. This tight range of temperatures should be strictly followed because the benefit to frozen tissues is reduced at lower temperatures and burn injury may occur at higher temperatures. Parenteral analgesia should be administered as needed for pain. Massage of the area is contraindicated because it may exacerbate the injury. After rapid rewarming, the standard protocol to prevent progressive tissue or dermal ischemia includes the following:

- Debride clear blisters;

- Leave hemorrhagic blisters intact and aspirate if infected;

- Elevate affected areas to decrease edema;

- Apply topical thromboxane inhibitor to injured areas;

- Give systemic antiprostaglandin agent (ie, acetylsalicylic acid, ibuprofen);

- Give tetanus toxoid prophylaxis when appropriate; and

- Whirlpool treatments to decrease the incidence of infection and early mobilization with passive manipulation of injured extremities are advocated when appropriate.

\section{The role of surgery in the treatment of frostbite}

Reconstruction has no role in the acute phase of frostbite. Attempts to debride aggressively in the early phase of frostbite or amputation may compromise viable tissue. The only indication for early operative intervention is to ameliorate a constricting eschar or to drain a subeschar infection that has not responded to topical antimicrobials. If tissue injury progresses to gangrene, amputation and/or coverage may be required. Surgery should be delayed until the area is thoroughly demarcated.

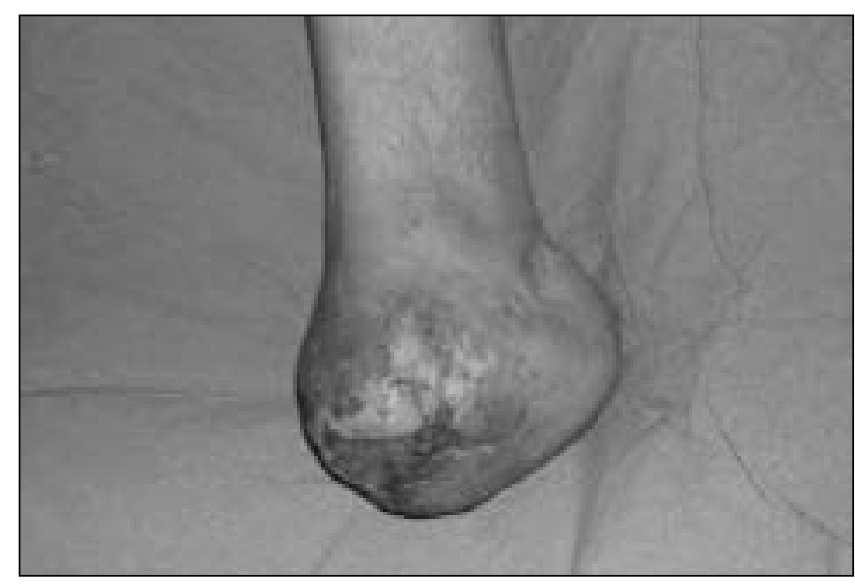

Figure 2) Amputation due to frostbite from the level of the talocalcaneonavicular joint of the foot

Late sequelae of frostbite

Arthritis is common after frostbite. Pain, hyperesthesia and cold sensitivity are more infrequent, and are seen in more severe cases. Hyperhydrosis and pigment changes may occur as well. Occurrence of epiphyseal insult in children and subsequent growth deformities may be also seen (7-9).

\section{CONCLUSION}

In the present review, most frostbite cases arrived at a major medical centre at a late stage (Figure 1). This may be related to the socioeconomic condition of this region, or because of the difficulty of transferring patients to main medical centres due to poor road conditions in winter. We also determined that frostbite that occurred faster progressed to gangrene, and as a result, many of these patients (especially chronic smokers) were treated by amputation (Figure 2). Most of the affected patients were farmers, soldiers and herders. In the early stages, patients with frostbite can recover without complication. However, if treatment is delayed, and if the patient has an associated disease (or is an chronic smoker), it can be a life-threatening situation.

\section{REFERENCES}

1. Petrone P, Kuncir EJ, Asensio JA. Surgical management and strategies in the treatment of hypothermia and cold injury. Emerg Med Clin North Am 2003;21:1165-78.

2. Segantini P, Horn R. [Cold-induced pathology at high altitude.] Schweiz Rundsch Med Prax 1991;80:1283-6.

3. Britt LD, Dascombe WH, Rodriguez A. New horizons in management of hypothermia and frostbite injury. Surg Clin North Am 1991;71:345-70

4. Wittmers LE Jr. Pathophysiology of cold exposure. Minn Med 2001;84:30-6.

5. Rintamaki $\mathrm{H}$. Predisposing factors and prevention of frostbite. Int J Circumpolar Health 2000;59:114-21.

6. Zook N, Hussmann J, Brown R, et al. Microcirculatory studies of frostbite injury. Ann Plast Surg 1998;40:246-53.

7. Fletcher JW, Patel JC. Frostbite. In: Weinzweig J, ed. Plastic Surgery Secrets. Philadelphia: Hanley \& Belfus, 1998:395-8.

8. Ranhoff AH. Accidental hypothermia in the elderly. Int J Circumpolar Health 2000;59:255-9.

9. Gage AM, Gage AA. Frostbite. Compr Ther 1981;7:25-30. 